\title{
A new fossil genus of Encyrtidae (Hymenoptera: Chalcidoidea) from Late Eocene Danish amber
}

\author{
Новый ископаемый род наездников семейства Encyrtidae \\ (Hymenoptera: Chalcidoidea) из позднеэоџенового датского янтаря
}

\author{
S.A. Simutnik \\ C.A. Симутник
}

Schmalhausen Institute of Zoology, 15 Bogdan Khmelnitsky St., 01601 Kiev-30, Ukraine. E-mail: sim@izan.kiev.ua. Институт зоологии имени И.И. Шмальгаузена, ул. Богдана Хмельницкого 15, 01601 Киев-30, Украина.

KEY WORDS: Chalcidoidea, Encyrtidae, Sulia gen.n., amber, Late Eocene.

КЛЮЧЕВЫЕ СЛОВА: Chalcidoidea, Encyrtidae, Sulia gen.n., янтарь, поздний эоцен.

ABSTRACT. Sulia glaesaria gen. et sp.n. is described and illustrated from Danish amber collection of the Zoological Museum of University of Copenhagen. A brief comparative morphological analysis of the new genus is made. As all previously described Encyrtidae of the Late Eocene amber fauna, the new genus is characterized by long veins of the forewing.

РЕЗЮМЕ. Sulia glaesaria gen. et sp.n. описан и проиллюстрирован из коллекции датского янтаря Зоологического музея Копенгагенского университета. Сделан краткий сравнительно-морфологический анализ нового рода. Как и все ранее описанные энциртиды фауны позднеэоценового янтаря, новый род отличается длинными жилками переднего крыла.

\section{Introduction}

Two encyrtid genera, Eocencyrtus Simutnik, 2001 and Eocencnemus Simutnik, 2002, have been described based on female specimens from the Late Eocene Rovno amber [Simutnik, 2001, 2002]. Another genus, Glaesus Simutnik, 2014, is described from the Baltic amber based on a male specimen [Simutnik et al., 2014]. One more encyrtid genus, Archencyrtus Simutnik, 2014, is known from the Middle Eocene Sakhalinian amber [Simutnik, 2014]. The first member of the family Encyrtidae from the Late Eocene Danish amber [Larsson, 1978] is described below. The material is deposited in the Zoological Museum of the University of Copenhagen (ZMUC). Photos are taken using microscope MBS-10 with digital camera Canon A-510.

\section{Genus Sulia Simutnik, gen.n.}

Figs 1-4.

Type species: Sulia glaesaria Simutnik, sp.n.

DESCRIPTION. Female. Body length $1.9 \mathrm{~mm}$; fore wing length $1.5 \mathrm{~mm}$. Head, ventral parts of thorax and gaster dark, dorsal part of thorax light.
Body compact, convex; head hypognathous, a little wider than mesosoma, with occipital margin sharp; frontovertex smooth or sculpture not visible, broader than its length (Fig. 4); ocelli in obtuse triangle; vertical eye diameter twice as long as intermalar distance, malar space with undulate sulcus; scrobal depression not deep, with distinct margin; antennal toruli situated at level of ventral eye margin; scape slender, not expanded; funicle six-segmented; pedicel conical, 1.5 times as long as wide and equal in length to first funicular segment (F1); clava 3-segmented, rounded apically, little wider than funiculus, as long as 3 preceding segments combined; number of mandibular teeth unknown.

Mesosoma: pronotum short, transverse; mesoscutum as long as scutellum, notauli absent; mesoscutum, axillae and scutellum smooth, with rare, dark setae; interior angles of axillae converging; scutellum slightly convex, its apex rounded; fore wing hyaline, about twice as long as broad; linea calva without filum spinosum; apical $1 / 3$ of submarginal vein of fore wing not broadened, all veins long, marginal setae very short; tarsus 5-segmented; midtibial spur thick, little shorter than first tarsomere; propodeum short, with large, convex lateral parts.

Metasoma: gaster as long as thorax, pygostyles are located near apex of gaster; hypopygium transverse, not reaching apex of metasoma; ovipositor almost not exserted, apical parts of third valvulae (V3) upcurved (lateral view) (Fig. 2).

Male. Unknown.

COMMENTS. Simutnik [2007] and Simutnik et al. [2014] provided extensive information about the details of forewing venation of the fossil Encyrtidae. As all previously described genera of the Late Eocene amber fauna, the new genus is characterized by long veins of the forewing. In the majority of the recent Encyrtidae, the marginal vein is either reduced or even missing.

ETYMOLOGY. The genus is named after I.A. Sulimenko.

Key to females of the Late Eocene genera of ENCYRTIDAE

1. Hypopygium triangular, reaching apex of metasoma ....... Eocencnemus Simutnik, 2002

- Hypopygium transverse, not reaching apex of metasoma 
2. Pygostyles closer to base of metasoma; 1 st to 4 th funicular segments small, ring-shaped

Eocencyrtus Simutnik, 2001

- Pygostyles closer to apex of metasoma; funicular segments longer their width or square Sulia gen.n.

\section{Sulia glaesaria Simutnik, sp.n. \\ Figs 1-4.}

MATERIAL. Holotype $\sigma^{7}$ ZMUC, 5-1-1961; Bòrge Mortensen, Danish amber, Late Eocene.

DESCRIPTION. Head dark. Eyes, ocelli, funicle, mandible and labial palpi yellowish brown. Scape of antenna brown with yellow apex. Pedicel brown. Venation of wings light. Coxae dark. Femora and tibiae dark with light apex. Tarsi light with apical segments dark. Details of sculpture of head, mesoscutum, and scutellum not visible. Proportions of head and antennal segments as on Figs 1, 2, 4. Mandibular teeth not visible. Location of setae along linea calva and forewing venation as on Fig. 3.

MEASUREMENTS ( $\mathrm{mm}$ ) of the holotype. Body length, 1.9 ; length of mesosoma, 0.9 ; length of metasoma, 0.8 .

ETYMOLOGY. From Latin "glaesum" (derived from an old Germanic word "glüzen" meaning "sparkle") that proba-

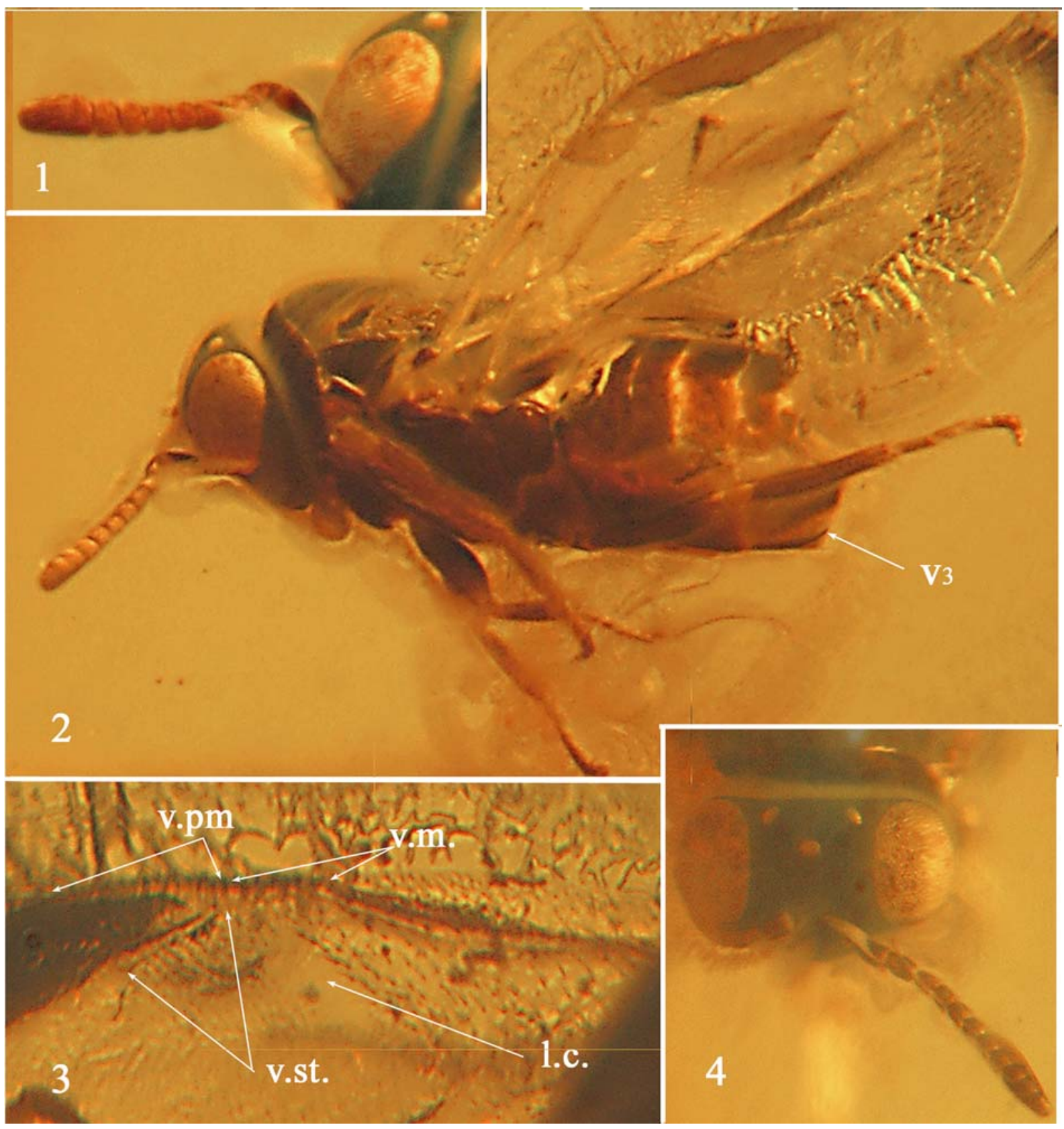

Figs 1-6. Sulia glaesaria gen. et sp.n., holotype $\mathrm{O}^{\mathrm{T}}$ : 1 — antenna and part of head, lateral view; 2 — habitus, lateral view (V3 — third valvula); 3 - forewing venation (1.c. - linea calva, v.m. - marginal vein, v.pm. — postmarginal vein, v.st. — stigmal vein); 4 - head, dorsal view.

Рис. 1-6. Sulia glaesaria gen. et sp.n., голотип О’: 1 - усик и часть головы, сбоку; 2 - общий вид, сбоку (V3 - третья вальвула); 3 — жилкование передних крыльев (1.c. — голая косая полоска, v.m. — маргинальная жилка, v.pm. — постмаргинальная жилка, v.st. — радиальная жилка); 4 - голова, сверху. 
bly was restricted to the valuable, glassy amber and was used to designate amber as well as glass.

ACKNOWLEDGMENTS. Lars Vilhelmsen (ZMUC) kindly arranged a loan of specimens and Evgeny Perkovsky (SIZK) provided valuable consultations and commentaries.

\section{References}

Larsson S.G. 1978. Baltic amber - a paleobiological study // Entomonograph. Vol.1. P.1-192.

Simutnik S.A. 2001. [A find of encyrtid wasp (Hymenoptera, Chalcidoidea, Encyrtidae) in Late Eocene Rovno amber (Ukraine)] // Vestnik Zoologii. Vol.35. P.81-84 [in Russian].
Simutnik S.A. 2002. [A new genus of encyrtid wasps (Hymenoptera, Chalcidoidea, Encyrtidae) from Late Eocene Rovno amber (Ukraine)] // Vestnik Zoologii. Vol.36. P.99-102 [in Russian]. Simutnik S.A. 2007. [Fossil encyrtids (Hymenoptera: Chalcidoidea: Encyrtidae) from the Rovno amber] // Izvestiya Kharkovskogo Entomol. Obshchestva. Vol.15. No.1-2. P.137-141 [in Russian].

Simutnik S.A., Perkovsky E.E., Gumovsky A.V. 2014. Review of the Late Eocene Encyrtidae (Hymenoptera, Chalcidoidea) with a Description of the First Fossil Genus with Filum Spinosum // Paleontological Journal. Vol.48. No.1. P.65-73.

Simutnik S.A. 2014. The First Record of Encyrtidae (Hymenoptera, Chalcidoidea) from the Sakhalin Amber // Paleontological Journal. Vol.48. No.6. P.621-623. 